\title{
Minireview
}

\section{The oldest records of photosynthesis}

\author{
Stanley M. Awramik \\ Department of Geological Sciences, Preston Cloud Research Laboratory, University of California, \\ Santa Barbara, CA 93106, USA
}

Received 1 September 1991; accepted in revised form 12 March 1992

Key words: cyanobacteria, stromatolites, fossil record, Archean

\begin{abstract}
There is diverse, yet controversial fossil evidence for the existence of photosynthesis 3500 million years ago. Among the most persuasive evidence is the stromatolites described from low grade metasedimentary rocks in Western Australia and South Africa. Based on the understanding of the paleobiology of stromatolites and using pertinent fossil and Recent analogs, these Early Archean stromatolites suggest that phototrophs evolved by 3500 million years ago. The evidence allows further interpretation that cyanobacteria were involved. Besides stromatolites, microbial and chemical fossils are also known from the same rock units. Some microfossils morphologically resemble cyanobacteria and thus complement the adduced cyanobacterial involvement in stromatolite construction. If cyanobacteria had evolved by 3500 million years ago, this would indicate that nearly all prokaryotic phyla had already evolved and that prokaryotes diversified rapidly on the early Earth.
\end{abstract}

\section{Introduction}

The pre-Phanerozoic (Precambrian) refers to geological time from the oldest terrestrial rocks known, 3960 million years ago, to the first records of diverse skeletal animals from the base of the Cambrian, about 540 million years ago. This immense span of geological time, some 3420 million years, is divided into two eons, the Archean (from 3960 to 2500 million years ago) and the Proterozoic (from 2500 to about 540 million years ago). The pre-Phanerozoic has a fossil record that is very distinct from that of the Phanerozoic. The biosphere was microbial. Prokaryotic phototrophs, including cyanobacteria, go back 3500 million years ago. Microbial prokaryotes dominated the first $70 \%$ of prePhanerozoic time while prokaryotes and microbial eukaryotes dominated the remaining 30\%. There were no plants; however, photosynthetic organisms represented by macroscopic algae are known from rocks as old as $1400-1500$ million years (Peat et al. 1978); yet, they are relatively rare in the fossil record. Microbial eukaryotes start to become abundant in the fossil record about 1000 million years ago. Animal fossils are found in only the youngest portion of the prePhanerozoic, the Vendian (from about 680 to 540 million years ago), and they consist of centimeter-size, soft-bodied animals (the so-called Ediacaran fauna) and relatively uncomplicated trace fossils produced by animals (Glaessner 1984). Animals diversified very rapidly in the latest pre-Phanerozoic and in the earliest Cambrian (Valentine et al. 1991).

The bulk of pre-Phanerozoic fossils falls into three categories: (1) microbial fossils, (2) stromatolites and (3) chemical fossils. Chemical fossils in the broad sense refer to chemical evidence for past life and include organic compounds and biologically fractionated stable isotopes, in particular, carbon. Stromatolites are macroscopic biosedimentary constructions, often in laminated domical to columnar shapes, pro- 
duced by the sediment trapping, binding, and/or precipitation activity of microorganisms. Photosynthetic microbes, in particular cyanobacteria, are integral to stromatolite construction. Microbial fossils refer to the remains of microscopic organisms preserved in rock. There are two broad informal categories of microfossils that are often defined by (1) the manner in which they are prepared for study-acritarchs, and (2) the rock that preserves the microfossils - chert microfossils. Chert microfossils are microbial fossils that are studied in petrographic thin sections of chert. Chert is a chemical sedimentary rock composed of microcrystals of silica. Typically, these fossils are viewed as they were three dimensionally permineralized by silica entombing them in the rock. Most chert microfossils are preserved in stromatolites and interpreted to be the remains of cyanobacteria (viz. Schopf 1968). Acritarchs are organic walled microfossils that are freed from the host sedimentary rock by dissolving the rock matrix using acids. Fine-grained, clastic sedimentary rocks, such as shale and mudstone, are the rocks of choice. The organisms that typify acritarchs had durable walls that survived the processes of fossilization and also attack by acid in the laboratory. They are often interpreted to represent cysts-forming phytoplanktonic algae (Vidal 1984).

\section{Pre-Phanerozoic paleontology}

The overall record of life in pre-Phanerozoic rocks has bearing on the interpretation of the oldest records of life from the early Archean. It provides experience in working with and understanding the nature of the fossil record before large, multicellular organisms appeared. Studies on well preserved, compelling Proterozoic microfossils (e.g., the ca. 2000 million-year-old Gunflint Iron Formation, Barghoorn and Tyler 1965, and the ca. 800 million-year-old Bitter Springs Formation, Schopf 1968) have furnished standards with which to evaluate putative microfossils, in particular those from the Archean (Cloud and Morrison 1979, Schopf and Walter 1983). These studies provide a guide for distinguishing fossil material from abiogenic fea- tures and examples of textural relationships indicating that the microfossils are of the same age as the sediment that made up the rock. Unfortunately, the success of these studies have also provided biases in searching for and interpreting pre-Phanerozoic fossils. Often, microbial fossils found in silicified stromatolites are interpreted as cyanobacteria because of their presence in stromatolites (e.g., Awramik and Semikhatov 1978). Rarely are lithologies other than chert, shale and mudstone collected and analyzed for microbial fossil content. Metamorphosed sedimentary rocks can also preserve microbial fossils (e.g., Kidder and Awramik 1990).

Stromatolites are commonly recognized by the total geometry of the structure. Laminated domes and columns, centimeters to decimeters in size, convex away from the site of initiation, are the most easily recognized shapes. Debate with regard to the definition of a stromatolite is semantic stemming, in part, from various translations and interpretations of Kalkowsky (1908) who introduced the term (see Hofmann 1969a, Semikhatov et al. 1979, Krumbein 1983). Biogenic versus abiogenic, laminated versus unlaminated, domical versus flat are questions discussed in those papers. Most stromatolite researchers follow, in a slightly modified form, the definition of Awramik and Margulis (in Walter 1976b, p 1): 'organosedimentary structures produced by the sediment trapping, binding, and/or precipitation activity of microorganisms, principally [cyanobacteria].' Therefore, by this definition, a stromatolite is a biogenic feature produced by microbes.

If some of the earliest microfossils were cyanobacteria preserved in a fossilized microbial mat (which is the interpretation in this paper), then, based on modern analogs (see Cohen and Rosenberg, Editors 1989), the microbial mat environment must have been metabolically diverse with anaerobes and aerobes. Repeatedly through the microfossil record in stromatolites, cyanobacteria are often the only type of microfossil found. One curious aspect of the pre-Phanerozoic fossil record is the predominance of remains that indicate photosynthesis: fossilized cyanobacteria and algae, stromatolites and the chemical fossils found. Why other groups of organisms posses- 
sing different metabolic pathways are not represented or are exceedingly rare is uncertain. Probably, for microbial fossils, it was some combination of chemical and physical processes of fossilization that favored these photosynthetic organisms because of readily permineralizable structures (such as sheaths or envelopes; Horodyski et al. 1977) and the environments they inhabited favored their permineralization (Knoll 1985). With regard to stromatolites, they are preserved almost exclusively as carbonate (limestone and dolostone), which suggests a possible relationship between photosynthesis (uptake of $\mathrm{CO}_{2}$ ) and carbonate precipitation (Golubic 1973).

\section{The evidence for life $\mathbf{3 5 0 0}$ million years ago}

Fossilized microbial remains, stromatolites and chemical fossils have been reported from early Archean rocks. The early Archean evidence is subjected to the highest standard of critical evaluation on the biogenicity and/or age of the alleged fossils with debates not uncommon. Why are these fossils subjected to this apparently inordinate scrutiny? Such fossils provide the material evidence for the existence of the earliest life on Earth and provide important benchmarks and/or constraints for evolutionary models on the earliest development of life.

Two regions, the Pilbara of Western Australia and the Barberton Mountain Land of South Africa, have been the focus of most of the activity with regard to the oldest evidence of life on Earth. Both areas contain thick sequences of the most ancient, relatively unmetamorphosed sediments known. The stratigraphic unit in South Africa is termed the Swaziland Supergroup and the Australian unit is called the Pilbara Supergroup. Each supergroup is subdivided into groups and formations. Microbial fossils, stromatolites, and chemical fossils have been reported from these regions (e.g., Awramik et al. 1983, Hayes et al. 1983, Byerly et al. 1986) indicating that the initial appearance and diversification of prokaryotes had already occurred. The discussions that follow are based on evidence for life discovered in these two supergroups.

\section{Chemical fossils}

Kerogen is insoluble, high-molecular-weight organic matter that represents the geologically stable end product of the burial of organic matter (McKirdy and Hahn 1982). Extreme care must be taken to ascertain the kerogen analyzed is syngenetic with deposition of the sediments and not a post-lithification contaminant (Hayes et al. 1983). Kerogen of an apparently syngenetic origin is found in the sedimentary rocks of both supergroups. The presence of the kerogen suggests the presence of ancient life. In these and younger Archean rocks, the kerogen preserves very few biosynthetic molecular skeletons and thus precludes detailed biogeologic conclusions (Hayes et al. 1983). More revealing, and a firmer foundation upon which to base chemical evidence for the existence of life, are the data on the ratios of the stable isotopes of carbon in the kerogen. The transformation of inorganic carbon $\left(\mathrm{CO}_{2}\right)$ via biosynthetic pathways associated with autotrophy into biological material involves the preferential incorporation of the lighter isotope, ${ }^{12} \mathrm{C}$, into the organics leaving behind a reservoir enriched in the heavier isotope, ${ }^{13} \mathrm{C}$. This heavier isotope can be incorporated in precipitated carbonate (see review by Schidlowski 1987). Carbon isotopic analyses of kerogen in chert from the Warrawoona Group (lowest lithostratigraphic group of the Pilbara Supergroup) and the Swaziland Supergroup vary from -34.3 to -36.1 $\delta^{13} \mathrm{C} \quad\left(\overline{\mathrm{x}}=-35.4 \quad \delta^{13} \mathrm{C} ; \mathrm{n}=4\right)$ and -26.6 to $-32.0 \delta^{13} \mathrm{C}\left(\overline{\mathrm{x}}=-30.8 \delta^{13} \mathrm{C} ; \mathrm{n}=7\right)$, respectively (Hayes et al. 1983). These stable carbon isotope values fall well within the range of autotropic carbon fixation involving ribulose-1,5-bis-phosphate carbolxylase (Schidlowski 1982, Brock 1989).

\section{Stromatolites}

Demonstrating the biogenic nature of early Archean stromatolites is not straightforward. Abiogenic, laminated, stromatolite-like structures are known such as laminated calcretes (formed in soils, Read 1976), spelothems (e.g., stalagmites, Thrailkill 1976) and geyserites (Walter 1976a). Thus, caution must be exercised 
when assigning a microbiological origin for various laminated sedimentary structures. A conservative approach would require the preservation of the microbial builders to prove the biogenic nature (Buick et al. 1981). However, based on many modern analogs and a rich Proterozoic record of stromatolites (some containing microbial fossils), one can conclude with a high degree of confidence the biogenic origin of a stromatolite based on its morphology at the microscopic and macroscopic level, and the interpreted environment of formation (see Walter 1983, pp. 189-190 for a detailed discussion). Stromatolites with wavy-laminated stratiform shapes, domes, columns (especially branching columns), possessing laminae greater 5 or $10 \mu \mathrm{m}$ thick that show gradational boundaries between the dark and light lamina, and which formed on the surface at the sediment/water interface in an aqueous setting (sea, lake, stream, thermal spring) are known to be the products of phototrophic microbial activity.

Stromatolites with wide ranges of shape (stratiform, domical, pseudocolumnar, columnar-layered, encapsulated or oncolitic) have been discovered in both the Pilbara and Swaziland sedimentary sequences. The domical stromatolites in the Warrawoona are up to $20 \mathrm{~cm}$ wide (Walter et al. 1980). Swaziland stromatolites are morphologically more complex than known Pilbara stromatolites. Individual domes and columns are smaller, ranging from 1 to $3 \mathrm{~cm}$ in diameter. Some constructions appear to have been bioherms or mounds, $>25 \mathrm{~cm}$ across, composed of pseudocolumnar stromatolites (Byerly et al. 1986, Fig. 3). In both regions, the stromatolites are well laminated with laminae ranging in thickness from 50 to $100 \mu \mathrm{m}$ for Swaziland (Byerly et al. 1986) and 20 to $100 \mu \mathrm{m}$ for Warrawoona stromatolites (Walter 1983).

The Warrawoona stromatolites have been subjected to some morphological modification by non-biological processes. The stromatolites formed in shallow, periodically exposed areas of the Pilbara basin associated with evaporite mineral formation (Groves et al. 1981). Growth of the evaporite mineral gypsum $\left(\mathrm{CaSO}_{4} \cdot \mathrm{H}_{2} \mathrm{O}\right)$ in or on the sediment would increase the volume of material and result in crinkling and folding of sediment layers. Gypsum formed syngenetically with sedimentation (Buick and Dunlop 1990) thus, it is uncertain how much volumetric expansion occurred. Periodic drying and wetting of sediment with a cohesive fabric also could have produced a wavy to folded configuration of the sedimentary layers. Gas within the sediment (possibly from microbial activity) trapped below an impermeable layer can produce a domical structure. The domical Warrawoona stromatolite described by Walter et al. (1980) has a hollow center that might represent a gas cavity.

These abiogenic processes, however, appeared to have modified the configuration of Warrawoona microbial mats and were not the primary processes responsible for the structures. Not all stromatolite domes have hollow centers (Fig. 1). The evaporite growth and the expansion/contraction caused by periodic wetting and drying would most likely produce fold-like structures with greatly exaggerated elliptical plan views (cross sections) rather than the circular to oval cross sections of the domes that are observed (see Fig. 3 in Lowe 1980b). The association of Recent and ancient stromatolites with evaporites and periodic wetting and drying is not uncommon (Muir 1987, Javor 1989). The irregular configurations imparted to the sediments by these processes are most likely possible if the sediment is cohesive and can respond plastically. The activity of microbes living in and on the sediment often confers the cohesive consistency necessary to support the plastic deformation (Fig. 2). Laminated, domical to cylindroidal

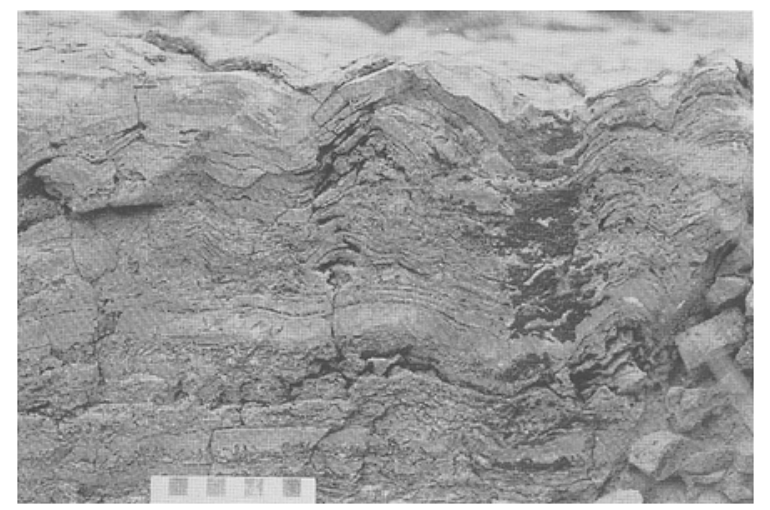

Fig. 1. Field photograph of domical to pseudocolumnar stromatolites from the early Archean Warrawoona Group, Western Australia. Formerly gypsum crystals are seen just above the centimeter scale. 


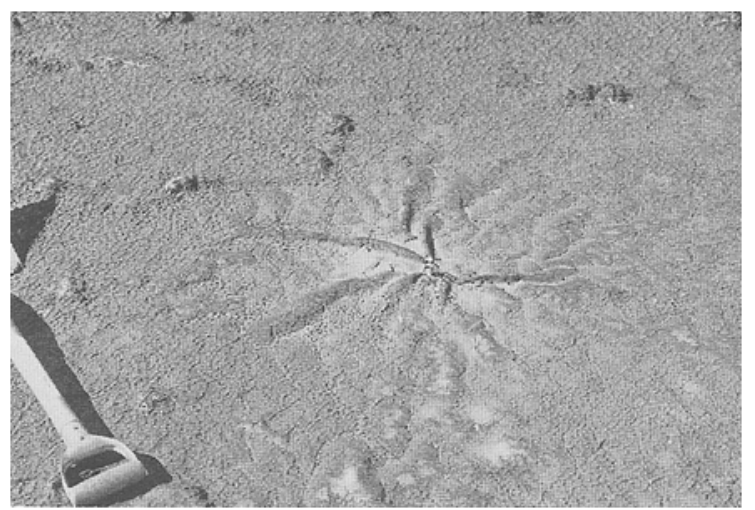

Fig. 2. A Recent crinkled and folded microbial mat constructed by the oscillatoriacean cyanobacterium Lyngbya aestuari; Shark Bay, Western Australia.

structures resembling stromatolites can form abiogenically in mud pools due to gas emanation (de Wit et al. 1982). However, these structures exhibit crosscutting and overlapping relationships that allow them to be differentiated from biogenic stromatolites.

Based on lamina thickness, the nature of the dark-light lamina boundaries, the domical to pseudo-columnar morphology of the structures, environmental setting, and comparisons with younger fossil and Recent analogs, the Warrawoona structures are interpreted as biogenic stromatolites.

The stromatolites described by Byerly et al. (1986) from the upper Onverwacht Group, Swaziland Supergroup, are morphologically more complicated than Warrawoona stromatolites. They consist of forms that range from domical to columnar-layered to pseudocolumnar in shape (Fig. 3). The stromatolites have compelling analogs among numerous Proterozoic and Phanerozoic stromatolites (for example, compare Fig. 3 with the stromatolite from the Gunflint Iron Formation illustrated in Hofmann 1969b, Plate 1, p. 35). Primary laminae in the stromatolite illustrated in Fig. 3 are 50 to $100 \mu \mathrm{m}$ thick (Byerley and Palmer 1991). Another clue consistent with their interpretation as biogenic stromatolites is the interpretation that the structures formed in a shallow, marine environment (Byerly et al. 1986, Byerly and Palmer 1991). No abiogenic processes are known that can produce laminated structures with this

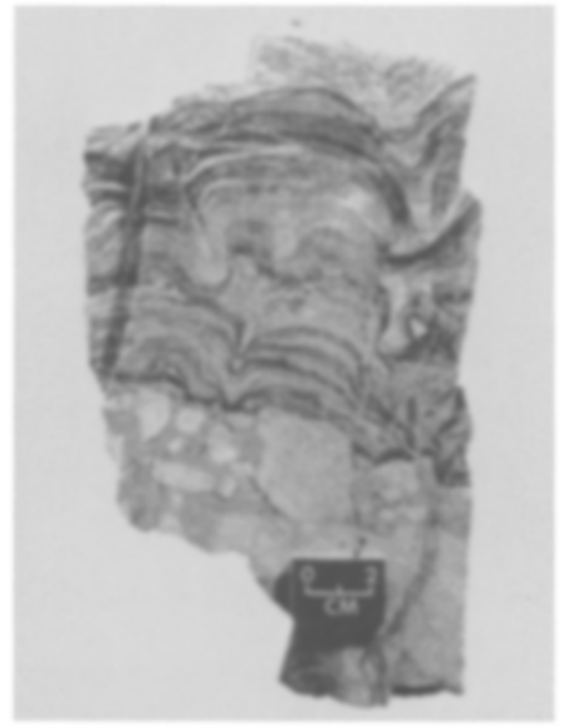

Fig. 3. Columnar-layered stromatolite from the early Archean Onverwacht Group (Swaziland Supergroup), South Africa. The photograph is courtesy of MM Walsh and GR Byerly, Louisiana State University.

morphology in shallow, marine environmental settings.

No microbial fossils are found in any of these domical, pseudo-columnar and columnar-layered early Archean stromatolites and thus their biogenicity might be questioned. However, the vast majority of fossil stromatolites despite age, lack microbial fossils. The interpretation of the early Archean stromatolites relies heavily on the understanding of, and comparison with, younger stromatolites and abiogenic, stromatolite-like structures, all within their environmental context. This is a powerful approach. Comparison of the Warrawoona and Swaziland stromatolites with younger, compelling examples of microbially produced stromatolites, is strong evidence for their biogenic origin.

\section{Microfossils}

Microbial fossils have been found in both the Swaziland and Pilbara sequences. In chert of the Warrawoona Group, four types of filamentous microbial fossils (Figs. 4 and 5, Awramik et al. 1983, Schopf and Packer 1987) and two types of coccoidal (spheroidal) microfossils (Schopf and Packer 1987) have been described. Controversy 


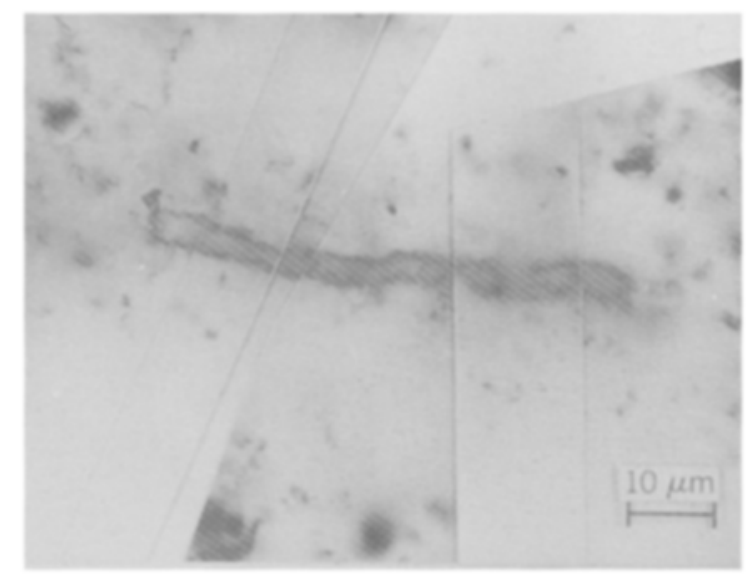

Fig. 4. Cylindrical, tubular microfossil within dark lamina in first generation chert of the early Archean Warrawoona Group, Western Australia. Photomontage constructed by photomicrographs taken at different focal depths within the petrographic thin section.

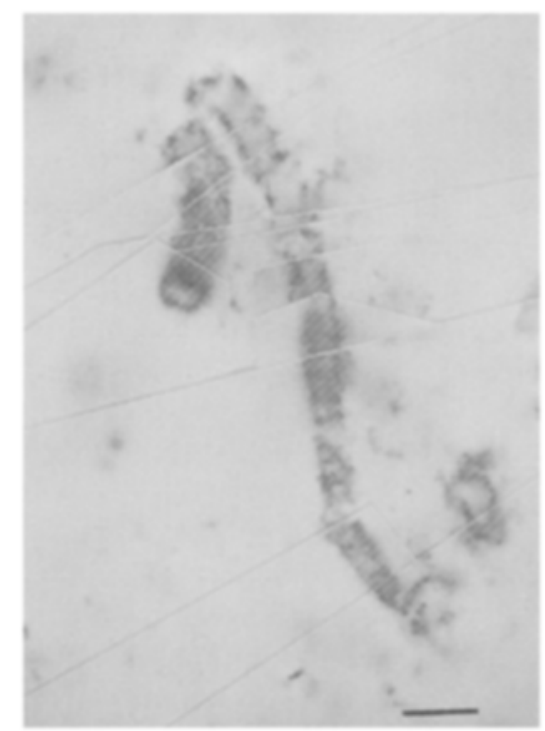

Fig. 5. Partitioned filamentous microfossil in first generation chert of the early Archean Warrawoona Group, Western Australia. Photomontage constructed by photomicrographs taken at different focal depths within the petrographic thin section. $\mathrm{Bar}=10 \mu \mathrm{m}$.

exists with regard to the biogenic and/or syngenetic nature of the filamentous Warrawoona microfossils (Awramik et al. 1983, 1988, Buick 1988, 1991). The two key elements of the controversy are: (1) At Locality A (one of two localities discussed in these papers), the exact layer and position from which a small piece of chert (about $5.5 \times 4 \times 6.5 \mathrm{~cm}$ ) collected in 1977 by Awramik containing the microfossils has never been pegged. The locality, outcrop and general portion of the outcrop for the sample are known (Awramik et al. 1983, 1988); however, attempts (as recently as July 1990 by Awramik) to relocate the precise spot where the sample was taken have failed. It is because of this failure to ascertain the precise position where the small sample was collected, combined with the complexities within sedimentary units of the Warrawoona and his work at Locality B that led Buick $(1984,1988,1991)$ to doubt the syngenicity of the filamentous fossils. He apparently does not question their biogenicity (Buick 1991). (2) Buick $(1984,1988,1991)$ has elegantly demonstrated that microfossil-like objects from Locality B of Awramik et al. (1983) are not verifiably biogenic nor are they syngenetic with the primary sediment. This confirmed what Awramik et al. (1983) originally presented and reaffirmed what Awramik et al. (1988) concluded with regard to the microfossil-like objects from this locality. This point appears to be lost by casual readers of the literature and played down by Buick. It was never stated or implied in Awramik et al. $(1983,1988)$ that bona fide microfossils of Warrawoona age occur in the chert at Locality B. Buick has misrepresented the evidence.

Detailed reexamination of petrographic thin sections of the fossil-bearing chert from Locality A, both those made for the initial study and new ones made for additional study, establish the following: (a) the filamentous microbial fossils originally described in Awramik et al. (1983) occur in the first generation of chert; (b) first generation chert preserves a laminated, stratiform fabric similar to fabrics observed in Proterozoic and younger stromatolites; (c) no microbial fossils were detected in later generations of chert; and (d) no filamentous microbial fossils or pseudofossils were found in cracks, fissures, or void spaces (Awramik et al. 1988). The filamentous fossils found at Locality $\mathrm{A}$ do not occur in chert from Locality B, $4.7 \mathrm{~km}$ away.

Schopf and Packer (1987) have reported on additional microbial fossils from two new Warrawoona localities. In addition to filaments about $3 \mu \mathrm{m}$ in diameter, two types of pluricellular 
spheroidal cell aggregates occur. One of these contains four cells (17 to $24 \mu \mathrm{m}$ in diameter) arranged in a multilammelated envelope. These most closely resemble chroococcalean cyanobacteria. The Schopf and Packer findings confirms the earlier evidence of bona fide microfossils in the Warrawoona.

The Swaziland Supergroup has been under investigation for microbial fossil evidence of life for many years starting with Pflug's 1966 report of filamentous and coccoidal microfossils from the 3300 million-year-old Fig Tree Group (Pflug 1966). Schopf and Walter (1983) summarized the status of putative microbial fossils in published reports and concluded that all, except the small spheroids described by many authors (e.g., Pflug 1966, Strother and Barghoorn 1980), were nonfossils. The spheroids are best referred to as 'dubiomicrofossils' because of great difficulty in confidently ascribing a biogenic nature to carbonaceous spheroids in such ancient rocks. Recent work by Walsh and Lowe (1985) and Walsh (1992) reports on new microfossil finds in the 3500 million-year-old Onverwacht Group of the Swaziland Supergroup. Summarized in Walsh (1992) and presented in Table 1, the putative microbial fossils are quite diverse and include small and large coccoids, threadlike (Fig. 6) and tubular filaments, in addition to spindle-shaped

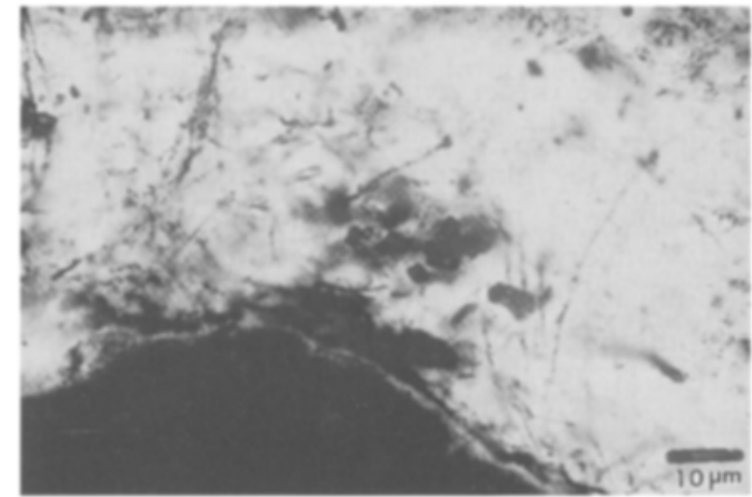

Fig. 6. Threadlike filamentous microfossils found coating and radiating from a sediment grain in chert of the early Archean upper Onverwacht Group, South Africa.

carbonaceous and pyritic morphs. Biogenicity and syngenicity of the microfossils are discussed and the Onverwacht age appears well established. Walsh (1992) discusses in detail the biogenicity of each morphotype and her conclusions range from bona fide microfossils to possibly dubiomicrofossils. As she points out, confidently establishing a biogenic origin is difficult. All these recently described microbial fossils will be the subject of future debate. The threadlike filaments, tubular filaments and small coccoids are strong candidates for bona fide microfossils.

Table 1. Morphotypes of early Archean microfossils

\begin{tabular}{|c|c|c|c|}
\hline Type & Diameter & Number found & Reference \\
\hline \multicolumn{4}{|c|}{ Warrawoona Group, Western Australia (CA. 3500 MA) } \\
\hline 1. pluricellular coccoid & 5.5 to $10.2 \mu \mathrm{m}$ & $\mathrm{N}=28$ & Schopf and Packer (1987) \\
\hline 2. pluricellular coccoid & 16.8 to $24.2 \mu \mathrm{m}$ & $N=4$ & Awramik et al. (1983) \\
\hline 3. threadlike filament & 0.3 to $0.7 \mu \mathrm{m}$ & $N>1200$ & Awramik et al. (1983) \\
\hline 4. tubular filament & 0.8 to $1.1 \mu \mathrm{m}$ & $N>260$ & Awramik et al. (1983) \\
\hline 5. tubular filament & 3.0 to $9.5 \mu \mathrm{m}$ & $\mathrm{N}>180$ & Awramik et al. (1983) \\
\hline 6. septated filament & 1.8 to $6.0 \mu \mathrm{m}$ & $\mathrm{N}=10$ & Awramik et al. (1983) \\
\hline \multicolumn{4}{|c|}{ Swaziland Supergroup, South Africa (CA. 3500 MA) } \\
\hline 1. solitary coccoid & 1.0 to $4.0 \mu \mathrm{m}$ & $N=200$ & Walsh and Lowe (1985) \\
\hline 2. ghost-like spheroid & 4.5 to $12.8 \mu \mathrm{m}$ & $\mathrm{N}=75$ & Walsh (1992) \\
\hline 3. thick-walled ellipsoid & 18 to $45 \mu \mathrm{m}$ by 47 to $78 \mu \mathrm{m}$ & NA & Walsh (1992) \\
\hline $\begin{array}{l}\text { 4. granular-walled } \\
\text { spheroidal to ellipsoidal }\end{array}$ & 10 to $84 \mu \mathrm{m}$ & $\mathrm{N}=41$ & Walsh (1992) \\
\hline 5. threadlike fillament & $<0.5$ to $2.5 \mu \mathrm{m}$ & NA & Walsh (1992) \\
\hline 6. hollow cylindrical filament & 1.5 to $2.5 \mu \mathrm{m}$ & NA & Walsh (1992) \\
\hline 7. large filamentous sheath & $5 \mu \mathrm{m}$ & $N=1$ & Walsh (1992) \\
\hline 8. spindle-shaped structure & 13 to $135 \mu \mathrm{m}$ & $\mathrm{N}=27$ & Walsh (1992) \\
\hline 9. lenticular structure & 30 to $50 \mu \mathrm{m}$ by 10 to $20 \mu \mathrm{m}$ & NA & Walsh (1992) \\
\hline
\end{tabular}




\section{Other evidence}

Besides the direct evidence for life in the early Archean discussed above, circumstantial evidence of a mineralogical nature, also exists. Gypsum was precipitated during Warrawoona and Onverwacht sedimentation in shallow, periodically exposed subaqueous environments not influenced by hydrothermal activity (Lambert et al. 1978, Worrell 1985). Gypsum precipitates from $\mathrm{SO}_{4}^{2-}$ in water. Sulfate forms from the oxidation of $\mathrm{S}^{0}$ or $\mathrm{H}_{2} \mathrm{~S}$ by sulfur-oxidizing bacteria and/or $\mathrm{O}_{2}$. Based on the current understanding of the sulfur cycle, this suggests that sulfur-oxidizing bacteria and/or oxygen-releasing photosynthesis were present in the early Archean (Lambert et al. 1978, Groves et al. 1981, Buick and Dunlop 1990). Sulfur-oxidizing bacteria include aerobic and anaerobic phototrophic (such as the green filamentous bacterium Chloroflexus, the purple sulfur bacterium Chromatium, and the green sulfur bacterium Chlorobium), and non-phototrophic (Beggiatoa) bacteria (Starr et al. 1981). Sulfur-oxidizing bacteria that oxidize $\mathrm{S}^{0}$ to $\mathrm{SO}_{4}^{2-}$, such as Beggiatoa and Thiobacillus, can do so under aerobic conditions (Kuenen and Tuovinen 1981, Schidlowski et al. 1983).

Although a surprisingly large array of diverse evidence has been presented for the existence of life 3500 million years ago, a number of the individual elements of the evidence are controversial while others are not compelling. When dealing with such ancient fossil material, there is no definitive test to prove the biogenicity and syngenicity of each type of evidence under consideration. In the absence of such 'proofs', it is prudent to proceed cautiously. However, the independent lines of evidence (chemical fossils, microfossils, stromatolites, gypsum, banded ironformations) taken together, converge on the one reasonable interpretation permitted: life existed 3500 million years ago.

\section{The evidence for photosynthesis $\mathbf{3 5 0 0}$ million years ago: $A$ case for the existence of cyanobacteria}

Banded iron-formations of the Archean and early Proterozoic have been used to imply the existence of oxygen-releasing photosynthetic organisms (e.g., Cloud 1973). Banded iron-formation is known from rocks as old as 3800 million years (Appel 1980) while the greatest volumes of banded iron-formation were deposited during the early Proterozoic ( 2500 to 2000 million years ago; Cloud 1988). The most likely source for the $\mathrm{O}_{2}$ necessary for the oxidation of $\mathrm{Fe}^{2+}$ to the iron oxides that produced the great volumes of iron-formation in the early Proterozoic, would be a biological source (Walker 1978). However, for older banded iron-formations that make up substantially less volume than their early Proterozoic counterparts, the photodissociation of water in the atmosphere can be considered another source for $\mathrm{O}_{2}$ and possibly the principal source 3800 million years ago (Walker et al. 1983). Alternatively, Cairnes-Smith (1978) proposed that iron-formation could form by photochemical reactions that extract oxygen from seawater. It is plausible that all three processes operated at different times in different environments in the Archean with biological oxygen becoming the major source by the early Proterozoic.

If the oxidation of reduced iron to produce banded iron-formations came exclusively from $\mathrm{O}_{2}$ released during photosynthesis, then this would provide definitive evidence for the existence of cyanobacteria. However, as discussed above, there are two other hypotheses, both abiogenic, for the origin of iron-formation.

Gypsum, as outlined above, indicates the presence of sulfur-oxidizing bacteria and/or oxygenreleasing cyanobacteria. Without sulfur-oxidizing bacteria, reduced sulfur can only be oxidized to sulfate by $\mathrm{O}_{2}$. The most likely source of geochemically useful $\mathrm{O}_{2}$ on the early Earth was oxygen-releasing phototrophy (Cloud 1976). With regard to sulfur-oxidizing bacteria, many are phototrophs (among the exceptions is Beggiatoa). The gypsum thus presents weakly constrained evidence for photosynthesis.

The carbon isotopic data on early Archean organic matter in sediments indicate that autotrophy existed: the Warrawoona rocks have $\delta^{13} \mathrm{C}$ values ranging from -34.3 to -36.1 and the Swaziland rocks -26.6 to $32.0 \delta^{13} \mathrm{C}$ (Hayes et al. 1983). These values are within known ranges of autotrophic carbon fractionation as outlined in 
Schidlowski (1982) but are on the light side for autrotrophs using ribulose-1,5-bisphosphate carboxylase (Brock 1989). It must also be kept in mind that at least three other $\mathrm{CO}_{2}$ fixation pathways are known in autotrophic, but non-phototrophic bacteria with $\delta^{13} \mathrm{C}$ values ranging from -8.2 to -35.1 (Preuss et al. 1989). In the phototrophs, green sulfur bacteria (e.g., Chlorobium limicola) and green filamentous bacteria (Chloroflexus aurantiacus) also do not have Rubisco (Evans et al. 1966, Holo and Grace 1987). For Chloroflexus the carbon isotopic fractionation is small, $\delta{ }^{13} \mathrm{C}=-13.7$ (Holo and Sirevag 1986). Nevertheless, Schidlowski (in press) concludes that the carbon isotopic data from the early Archean are consistent with the interpretation that cyanobacteria had already appeared by 3500 million years ago.

Paleobiological interpretations with regard to the function, physiology, and affinities of the life represented in the early Archean fossil record are fraught with difficulties. Independent lines of evidence indicate that phototrophy had already evolved by 3500 million years ago (e.g., Awramik et al. 1983, Walter 1983) and support the earlier contentions that cyanobacteria were among these phototrophs (e.g., Lowe 1980b, Awramik 1981).

Microbial fossils, representing direct evidence of ancient life and the focus of the greatest attention, often do not provide definitive paleobiological information on the level of evolution. As outlined in Awramik et al. (1983), Schopf and Walter (1983), and Walsh 1992), assigning affinities to 3500 million-year-old microfossils is difficult. With fossil microbes, only the three-dimensional morphology, commonly defined by carbonaceous material, is observed. Many phyla of prokaryotes contain morphologically similar taxa, a number of which resemble the fossil morphs and taxa described from South Africa and Australia. Thus, interpretations of the paleobiology of microbial fossils are limited. A variety of other evidence, much of it circumstantial, often comes into play.

There are, however, some morphological lines of evidence that permit the conclusion that phototrophs and even cyanobacteria existed 3500 million years ago. The presence, in Warrawoona rocks, of empty, tubular structures, and par- titioned filaments resembling trichomes, suggest that some of the microbes were motile and photoresponsive (Awramik et al. 1983, Schopf and Walter 1983, Schopf and Packer 1987). The preservation of the filaments commonly parallel to and within the dark laminae that resemble stromatolitic laminae (Fig. 4) support this contention. The large coccoids enclosed in a common wall-like structure described by Schopf and Packer (1987) from Warrawoona rocks provide striking morphological evidence for the existence cyanobacteria.

Stromatolites also provide presumptive evidence for the existence of cyanobacteria 3500 million years ago. It is my opinion that stromatolites provide stronger evidence for cyanobacteria than do many microfossils. Walter (1983, p 212) summarized his assessment of the microbes responsible for known early Archean stromatolites as follows: '[they] were constructed by filamentous prokaryotes (e.g., those of the Warrawoona Group) and possible by unicellular prokaryotes (e.g., those of the Onverwacht Group), among which were autotrophs. It is probable that the principal stromatolite-builders were phototactic, photoautotrophic and produced mucus sheaths'. These attributes, however, are also found in Chloroflexus-like mat-building organisms and therefore caution must be exercised in cyanobacterial interpretations.

Construction of stromatolites is not a simple, straightforward enterprise for microorganisms. Keep in mind, a stromatolite is a biosedimentary construction produced by the interaction of sediment and microbes. The activity/influence that microbes impart to sedimentary processes result in microbe-sediment laminae that often depart from the horizontal, planar layering that normally occurs with the deposition of fine-grained sediments. The microbes produce an actively accreting surface at the sediment-fluid interface that, through a poorly understood combination of environmental factors and behavioral responses in the microbes, generate convexities (domes, etc.) away from their site of initiation (Semikhatov et al. 1979). In order for a benthic, attached, non-dormant microbe that has required resources in the overlying fluid to live at the sediment-fluid interface in an environment subject to sedimentation, certain attributes are 
necessary. With regard to the benthic habit, there are at least four conceivable solutions: (a) density greater than the fluid, (b) entwinement with sedimentary particles, (c) an attachment system that anchors a portion of the microorganism in or on the sediment and (d) a sticky outside covering that secures the microbe to the substrate. Besides being secured to the sediment, rapid growth and/or motility is necessary. Unless the microbe has some means to maintain itself at a minimally functional level in or on the sediment, it will get buried. If attached to the substrate, tropism or tactic response to some stimulus is necessary in order for the microbe to orient in a manner that will minimize the effects of sedimentation and maximize exposure to useful and necessary resources in the overlying fluid medium. Motility or movement is a distinct advantage to organisms living at or near the sediment-fluid interface. It normally requires a stimulus, either to or away from something. Burial by sediment can be avoided by the ability to move or grow in the direction of accretion faster than the rate of sedimentation.

There are many chemical and physical stimuli that could provide the signal for responses mentioned above. The environments where stromatolites commonly form, narrow the possibilities. Stromatolites are most common in shallow, aqueous environments. This was the setting for early Archean stromatolites and is true for almost all Proterozoic (e.g., Bertrand-Sarfati and Moussine-Pouchkine 1985), Phanerozoic (e.g., Kennard and James 1986), and Recent stromatolites (e.g., Dill et al. 1986). Sunlight would be a most readily available resource and provide an excellent stimulus for taxes and tropisms in microbes living at the sediment-fluid interface. The designer microbe for stromatolite construction would therefore be a positive photoresponsive microbe capable of movement and/or growth in an environment subject to sedimentation. Positive photoresponsive prokaryotic microbes are often phototrophic.

Recent stromatolites are commonly built by cyanobacteria (Golubic 1976) and sometimes, by combinations of cyanobacteria and other phototrophs (cyanobacteria and green filamentous bacteria such as Chloroflexus, Castenholz 1984, cyanobacteria and diatoms, Awramik and Riding
1988). Two notable exceptions to the cyanobacterial generalization occur in (1) some thermal springs where combined high temperature and elevated hydrogen sulfide concentrations exclude cyanobacteria but allow such phototrophs such as Chloroflexus, Chromatium and Chlorobium (Ward et al. 1989) and (2) hydrothermal vents where non-phototrophic microbes produce mats (Belkin and Jannasch 1989) but it is uncertain if organosedimentary structures are produced. Analysis of the depositional environment of ancient stromatolites can distinguish between ancient thermal springs, hydrothermal vents and marine, lacustrine and fluviatile environments. The environment for the early Archean stromatolites is interpreted as shallow, near shore, and probably marine that excludes serious consideration of thermal spring and vent settings.

A testable consequence of the hypothesis that ancient stromatolites were primarily the products of cyanobacterial activity is the record of microfossils in ancient stromatolites. Schopf and Walter (1983) in Photo 9-10 illustrate a striking example of a sheathed, oscillatoriacean-like cyanobacterium from late Archean stromatolites. A number of Proterozoic stromatolites and Cenozoic (younger than 65 million years ago) stromatolites contain microbial remains. Based on size and morphological similarities, the predominant microfossils found preserved within stromatolic laminae have strong resemblances to cyanobacteria (Schopf 1968, Hofmann 1976, Schopf and Sovietov 1976, Awramik and Barghoorn 1977, Casanova and Nury 1989). Few microbes preserved in fossilized stromatolites resemble phyla other than cyanobacteria.

\section{Cyanobacteria 3500 million years ago}

The existence of cyanobacteria 3500 million years ago can be inferred from the stromatolite evidence and some of the microfossils as was discussed above. All the additional evidence known is consistent with such an hypothesis although less probable models do merit consideration (i.e., the stromatolites were constructed by phototrophic bacteria other than cyanobacteria, such as Chloroflexus, or by non-phototrophic 
bacteria). Whereas the fossil evidence is taken by some researchers of bacterial photosynthesis to indicate phototrophs by 3500 million years ago, there is a reluctance to conclude that cyanobacteria and oxygenic photosynthesis evolved by this time (e.g., Olson and Pierson 1986). Photosystem II (oxygenic photosynthesis) is a much more complex bioenergetic system (Vermaas 1989) than Photosystem I (anoxygenic photosynthesis, Olson and Pierson 1987) and is viewed as a major evolutionary innovation (e.g., Olson 1978) that would have evolved later (Pierson and Olson 1989). With regard to the timing and the evolution of complexity, major innovations and diversifications can occur over geologically short intervals of time. For instance, animal phyla diversified rapidly over a few to several tens of millions of years during the latest Proterozoic through Early Cambrian (Valentine et al. 1991). It is not known, however, which takes longer, the evolution of new physiological/metabolic pathways or the evolution of new structural designs (body plans). A long interval of time required for the biochemical and structural changes necessary for evolution within phototrophic bacteria leading to cyanobacteria may be unnecessary.

If cyanobacteria had evolved by 3500 million years ago, were they oxygen releasing, i.e., oxygenic phototrophs? Both anoxygenic (Photosystem I) and oxygenic (Photosystem II) photosynthesis occur in extant cyanobacteria (Cohen et al. 1975). There are no a priori reasons to exclude oxygenic photosynthesis 3500 million years ago. The fossil record permits the interpretation. Oxygen releasing phototrophy, once it evolved, could have played a relatively minor role in the microbial biosphere during the Archean because of difficulty maintaining relatively stable microaerophilic conditions in an environment rich in reduced compounds. The $\mathrm{O}_{2}$ produced by the cyanobacteria may have remained and been utilized within the microbial mat. Oxygen-releasing cyanobacteria occur within Recent microbial mats under anoxic sulfide conditions without any $\mathrm{O}_{2}$ exchange with the surrounding environment (Jørgensen and Nelson 1988). In addition, the dominant depositional settings of the Archean were sites of somewhat rapid sedimentation in tectonically active basins, the so-called greenstone belts (Lowe 1980a). Shallow, well-lit aqueous environments were of limited extent along the margins of the basins, and provided a somewhat small habitable area for phototrophs. This would have put selective pressures on the benthic microbes that required resources in the overlying water column to cope with sedimentation to maintain themselves at functional levels. Of all the microbial phototrophs known, cyanobacteria appear to be the best adapted to coping with active sedimentation. Nevertheless, compared with the Proterozoic, Archean stromatolites are rare (Walter 1983); less than 20 occurrences are known. It was not until the development of thicker, relatively stable continental crust (starting about 3000 million years ago) that characterizes the Proterozoic, that widespread shallow marine environments were common, sedimentation rates were reduced and stromatolites began to become common. An adaptive radiation of cyanobacteria occurred during this interval (see Cloud 1976 and Knoll 1984).

The consequences of cyanobacteria having evolved by 3500 million years ago are significant. Based on 16S rRNA sequence comparisons of eubacteria (Fig. 7), cyanobacteria were among the most recent of all eubacterial phyla to have evolved (Woese 1987). Just within the five phyla of phototrophic eubacteria, cyanobacteria are the most recent (Fig. 7, Pierson and Olsen 1989). Therefore, the presence of cyanobacteria would indicate that prokaryotic evolution and diversification at high taxonomic levels occurred very early on the Earth.

Early Archean cyanobacteria do not necessarily require that the origin of life be pushed back before some of the current estimates of 4000 million years ago (Miller 1982, Pace 1991). There is a complication to this. Life, had it originated before about 3800 million years ago, would have been subjected to large asteroidal impacts that possibly led to its extinction in shallow environments (Sleep et al. 1989). This nevertheless leaves 300 to 500 million years for life's origin and diversification to the cyanobacterial level as postulated here. The fossil record will determine the time of appearance of new organisms. Rates of evolution must be tied to the fossil record. The possibility of cyano- 


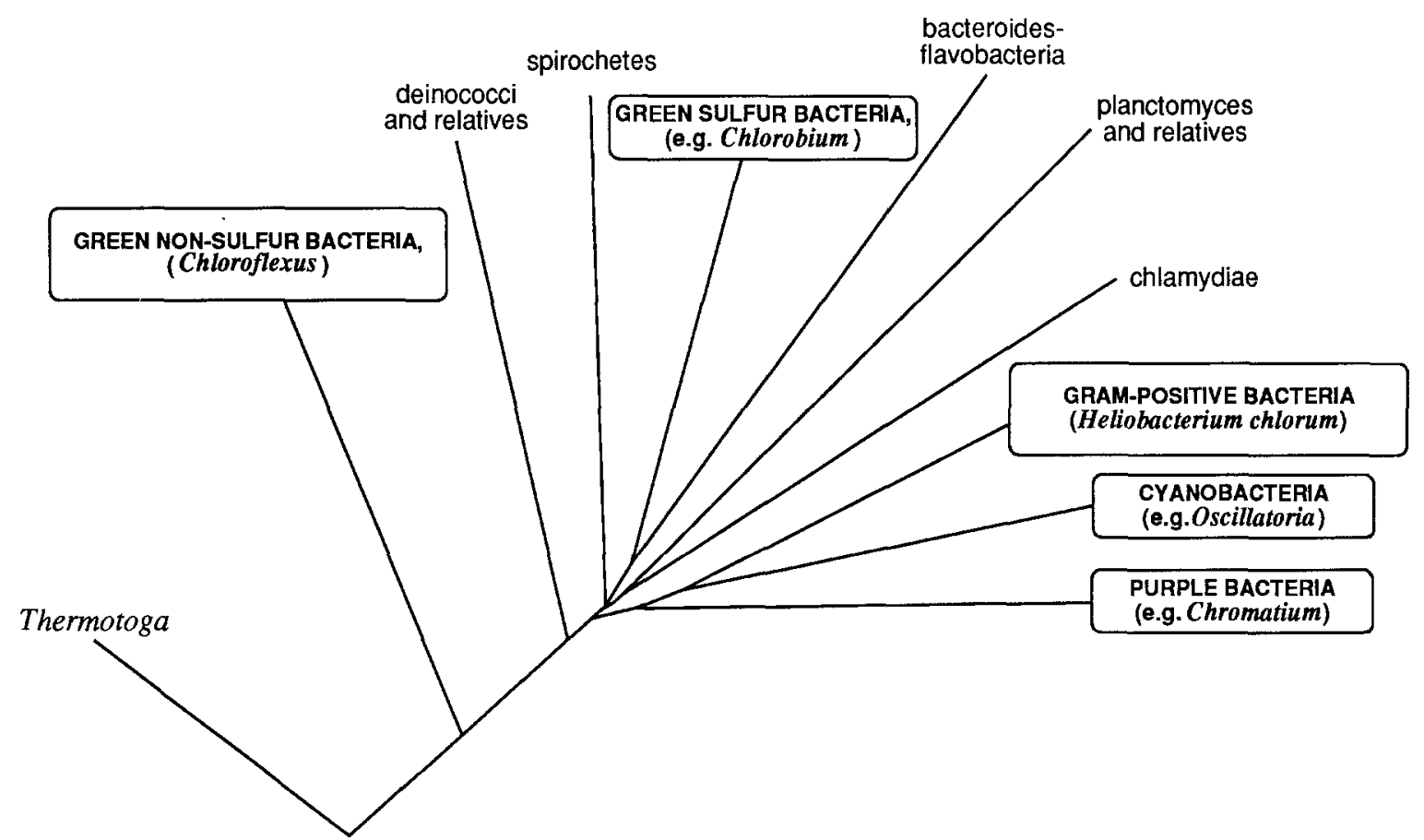

Fig. 7. Eubacterial phylogenetic tree based on 16S rRNA. The phototrophic bacteria are in boxes (modified somewhat from Woese 1987 and Pierson and Olson 1989).

bacteria 3500 million years ago must not be excluded on the grounds of a 'slow' model for prokaryotic evolution that requires many hundreds of millions of years for the development of new metabolic pathways and for new phyla. The 300 to 500 million years is considered adequate time for all the evolutionary innovations necessary to achieve the cyanobacterial level of evolution.

The fossil record indicates that by 3500 million years ago, cyanobacteria had evolved. Early Archean prokaryotes were diverse and probably occupied many habitats. Most or all prokaryotic phyla had evolved by this time and subsequent prokaryotic evolution was at lower taxonomic levels.

\section{Acknowledgements}

I thank Hyman Hartman for the opportunity to present this paper at the Symposium on the Origin of Photosynthesis in July 1990. This manuscript was begun while I was a Research Associate of the Western Australian Museum, Perth, Western Australia. Maude Walsh and
Gary Byerly provided unpublished information on the early Archean fossils of South Africa and Fig. 3. David Pierce, Robert Trench and Beverly Pierson commented on the manuscript. Financial support from NASA NAGW-1948 is greatly appreciated.

\section{References}

Apel PWU (1980) On the early Archaean Isua iron-formation, West Greenland. Precambrian Res 11: 73-87

Awramik SM (1981) The pre-Phanerozoic biosphere - three billion years of crises and opportunities. In: Nitecki $\mathrm{MH}$ (ed) Biotic Crises in Ecological and Evolutionary Time, pp 83-102. Academic Press, New York

Awramik SM and Barghoorn ES (1977) The Gunflint microbiota. Precambrian Res 5: 121-142

Awramik SM and Riding R (1988) Role of algal eukaryotes in subtidal columnar stromatolite formation. Proc Natl Acad Sci USA 85: 1327-1329

Awramik SM, Schopf JW and Walter MR (1983) Filamentous fossil bacteria from the Archean of Western Australia. Precambrian Res 20: 357-374

Awramik SM, Schopf JW and Walter MR (1988) Carbonaceous filaments from North Pole, Western Australia: Are they fossil bacteria in Archean stromatolites? A discussion. Precambrian Res 39: 303-309 
Barghoorn ES and Tyler SA (1965) Microorganisms from the Gunflint chert. Science 147: 563-577

Belkin S and Jannasch HW (1989) Microbial mats at deepsea hydrothermal vents: New observations. In: Cohen Y and Rosenberg E (eds) Microbial Mats, pp 16-21. Am Assoc Microbiol, Washington, DC

Bertrand-Sarfati J and Moussine-Pouchkine A (1985) Evolution and environmental conditions of the Conophyton associations in the Atar Dolomite (Upper Proterozoic), Mauritania. Precambrian Res 29: 207-234

Brock TR (1989) Evolutionary relationships of the autotrophic bacteria. In: Schlegel HG and Bowen B (eds) Autotrophic Bacteria, pp 499-512. Science Tech Publ, Madison

Buick R (1984) Carbonaceous filaments from North Pole, Western Australia: Are they fossil bacteria in Archaean stromatolites? Precambrian Res 24: 157-172

Buick R (1988) Carbonaceous filaments from North Pole, Western Australia: Are they fossil bacteria in Archaean stromatolites? A reply. Precambrian Res 39: 311-317

Buick R (1991) Microfossil recognition in Archean rocks: An appraisal of spheroids and filaments from a 3500 m.y. old chert-barite unit at North Pole, Western Australia. Palaios 5: $411-459$

Buick R and Dunlop JSR (1990) Evaporitic sediments of early Archean age from the Warrawoona Group, North Pole, Western Australia. Sedimentology 37: 247-277

Buick R, Dunlop JSR and Groves DI (1981) Stromatolite recognition in ancient rocks: An appraisal of irregularly laminated structures in an Early Archaean chert-barite unit from North Pole, Western Australia. Alcheringa 5: 161181

Bylerly GR and Palmer MR (1991) Tourmaline mineralization in the Barberton Greenstone Belt, South Africa: Early Archean metasomatism by evaporite-derived boron. Contr Miner Petrol 107: 387-402

Byerly GR, Lowe DR and Walsh MM (1986) Stromatolites from the 3,300-3,500-Myr Swaziland Supergroup, Barberton Mountain Land, South Africa. Nature 319: 489491

Cairnes-Smith AG (1978) Precambrian solution chemistry, inverse segregation, and banded iron formations. Nature 276: $807-808$

Casanova J and Nury D (1989) Biosedimentologie des stromatolites fluvio-lacustres du fosse oligocene de Marseille. Bull Soc Geol France 6: 1173-1184

Castenholz RW (1984) Composition of hot springs microbial mats: A summary. In: Cohen Y, Castenholz RW and Halvorson HO (eds) Microbial Mats: Stromatolites, pp 101-119. AR Liss, New York

Cloud P (1973) Paleoecological significance of the banded iron-formation. Econ Geol 68: 1135-1143

Cloud P (1976) Beginnings of biospheric evolution and their biogeochemical consequences. Paleobiology 2: 351-387

Cloud P (1988) Oasis in Space, 508 pp. W.W. Norton, New York

Cloud P and Morrison K (1979) On microbial contaminants, micropseudofossils, and the oldest records of life. Precambrian Res 9: 81-91

Cohen Y and Rosenberg E (Eds) (1989) Microbial Mats.
American Society for Microbiology, 494 pp. Washington, D.C.

Cohen Y, Jørgensen BB, Paden E and Shilo M (1975) Sulfide-dependent anoxygenic photosynthesis in the cyanobacterium Oscillatoria limnetica. Nature 257: 489-491

de Wit MJ, Hart R, Martin A and Abbott P (1982) Archean abiogenic and probable biogenic structures associated with mineralized hydrothermal vent systems and regional metasomatism, with implications for greenstone belt studies. Econ Geol 77: 1783-1802

Dill RF, Shinn EA, Jones AT, Kelly $K$ and Steinen RP (1986) Giant subtidal stronatolites forming in normal salinity waters. Nature $324: 55-58$

Glaessner MF (1984) The Dawn of Animal Life, 244 pp. Cambridge Univ. Press, Cambridge

Golubic S (1973) The relationship between blue-green algae and carbonate deposits. In: Carr N and Whitton BA (eds) The Biology of Blue-Green Algae, pp 434-472. Blackwell, Oxford

Golubic S (1976) Organisms that build stromatolites. In: Walter MR (ed) Stromatolites, pp 113-126. Elsevier, Amsterdam

Groves DI, Dunlop JSR and Buick R (1981) An early habitat for life. Sci Am 245: 64-73

Hayes JM, Kaplan IR and Wedeking KW (1983) Precambrian organic geochemistry: Preservation of the record. In: Schopf JW (ed) Earth's Earliest Biosphere, pp 93-134. Princeton Univ. Press, Princeton

Hofmann HJ (1969a) Attributes of stromatolites. Geol Surv Canada, Paper 69-39, 58 pp

Hofmann HJ (1969b) Stromatolites from the Proterozoic and Sibley Groups, Ontario. Geol Surv Canada, Paper 68-69, $77 \mathrm{pp}$

Hofmann HJ (1976) Precambrian microflora, Belcher Islands, Canada: Significance and systematics. J Paleontol 50: $1040-1073$

Holo H and Grace D (1987) Polyglucose synthesis in Chloroflexus aurantiacus studied by ${ }^{3} \mathrm{C}-\mathrm{NMR}$. Arch Microbiol 148: 292-297

Holo $\mathrm{H}$ and Sirevag R (1986) Autotrophic growth and $\mathrm{CO}_{2}$ fixation of Chloroflexus aurantiacus. Arch Microbiol 145: $173-180$

Horodyski RJ, Bloeser B and Vonder Haar S (1977) Laminated algal mats from a coastal lagoon, Laguna Mormona, Baja California, Mexico. J Sediment Petrol 47: 680-696

Javor B (1989) Hypersaline Environments, 328 pp. SpringerVerlag, Berlin

Jørgensen BB and Nelson DC (1988) Bacterial zonation, photosynthesis, and spectral light distribution in hot spring microbial mats of Iceland. Microb Ecol 16: 133-147

Kalkowsky E (1908) Oolith und Stromatolith im norddeutschen Buntsandstein. Dtsch Geol Ges 60: 68-125

Kennard JM and James NP (1986) Thrombolites and stromatolites: Two distinct types of microbial structures. Palaios 1: 492-503

Kidder DL and Awramik SM (1990) Acritarchs in lower greenschist facies argillite or the Middle Proterozoic Libby formation, upper Belt Supergroup, Montana. Palaios 5: $124-133$

Knoll AH (1984) The Archean/Proterozoic transition: A 
sedimentary and paleobiological perspective. In: Holland HD and Trendall AF (eds) Patterns of Change in Earth Evolution, pp 221-242. Springer-Verlag, Berlin

Knoll AH (1985) Exceptional preservation of photosynthetic organisms in silicified carbonates and silicified peats. Phil Trans R Soc London B 311: 111-122

Knoll AH, Barghoorn ES and Awramik SM (1978) New microorganisms from the Aphebian Gunflint Iron Formation, Ontario. J Paleontol 52: 976-992

Krumbein WE (1983) Stromatolites - The challenge of a term in space and time. Precambrian Res 20: 493-531

Kuenen JG and Tuovinen OH (1981) The genera Thiobacillus and Thiomicrospira. In: Starr MP, Stolp H, Trüper HG, Balows A and Schlegel HG (eds) The Prokaryotes, Vol 1, pp 1023-1036. Springer-Verlag, Berlin

Lambert IB, Donnelly TH, Dunlop JSR and Groves DI (1978) Stable isotopic compositions of early Archaean sulphate deposits of probable evaporitic and volcanogenic origin. Nature 276: 808-811

Lowe DR (1980a) Archean sedimentation. Ann Rev Earth Planet Sci 1980 8: 140-194

Lowe DR (1980b) Stromatolites 3,400-Myr old from the Archean of Western Australia. Nature 284: 441-443

McKirdy DM and Hahn JH (1982) The composition of kerogen and hydrocarbons in Precambrian rocks. In: Holland HD and Schidlowski M (eds) Mineral Deposits and the Evolution of the Biosphere, pp 123-154. SpringerVerlag, Berlin

Miller SL (1982) Prebiotic synthesis of organic compounds. In: Holland HD and Schidlowski M (eds) Mineral Deposits and the Evolution of the Biosphere, pp 155-176. SpringerVerlag, Berlin

Muir MD (1987) Facies models for Australian Precambrian evaporites. In: Peryt T (ed) Evaporite Basins, pp 5-21. Springer-Verlag, Berlin

Olson JM (1978) Precambrian evolution of photosynthetic and respiratory organisms. In: Hecht MK, Steere WC and Wallace B (eds) Evolutionary Biology, Vol 11, pp 1-37. Plenum, New York

Olson JM and Pierson BK (1986) Photosynthesis 3.5 thousand million years ago. Photosynth Res 9: 251-259

Olson JM and Pierson BK (1987) Evolution of reaction centers in photosynthetic prokaryotes. Int Rev Cytol 108: 209-248

Pace NR (1991) Origin of life - Facing up to the physical setting. Cell 65: 531-533

Peat CJ, Muir MD, Plumb KA, McKirdy DM and Norvick MS (1978) Proterozoic microfossils from the Roper Group, Northern Territory, Australia, BMR J Austr Geol Geophys 3: 1-17

Pflug HD (1966) Structured organic remains from the Fig Tree Series of the Barberton Mountain Land. Univ. Witwatersrand Econ Geol Res Unit Info Circ, 28, $14 \mathrm{pp}$

Pierson BK and Olson JM (1989) Evolution of photosynthesis in anoxygenic photosynthetic procaryotes. In: Cohen $\mathrm{Y}$ and Rosenberg E (eds) Microbial Mats, pp 402-427. Am Assoc Microbiol, Washington, DC

Preuss A, Schauder R and Fuchs G (1989) Carbon isotopic fractionation by autotrophic bacteria with three different $\mathrm{CO}_{2}$ fixation pathways. Z Naturforsch 44c: 397-402
Read JF (1976) Calcretes and their distinction from stromatolites. In: Walter MR (ed) Stromatolites, pp 55-71. Elsevier, Amsterdam

Schidlowski M (1982) Content and isotopic composition of reduced carbon in sediments. In: Holland HD and Schidlowski M (eds) Mineral Deposits and the Evolution of the Biosphere, pp 103-122. Springer-Verlag, Berlin

Schidlowski M (1987) Application of stable carbon isotopes to early biochemical evolution on Earth. Ann Rev Earth Planet Sci 15: 47-72

Schidlowski M (1992) The initiation of biological precesses on Earth: Summary of empirical evidence. In: Engel MH and Macko SA (eds) Organic Geochemistry. Plenum, New York (in press)

Schidlowski M, Hayes JM and Kaplan IR (1983) Isotopic inferences of ancient biochemistries: Carbon, sulfur, hydrogen and nitrogen. In: Schopf JW (ed) Earth's Earliest Biosphere, pp 149-186. Princeton Univ. Press, Princeton

Schopf JW (1968) Microflora of the Bitter Springs Formation, late Precambrian, central Australia. J Paleontol 42: 651-688

Schopf JW and Sovietov YuK (1976) Microfossils in Conophyton from the Soviet Union and their bearing on Precambrian biostratigraphy. Science 193: 143-146

Schopf JW and Walter MR (1983) Archean microfossils: New evidence of ancient microbes. In: Schopf JW (ed) Earth's Earliest Biosphere, pp 214-239. Princeton Univ. Press, Princeton

Schopf JW and Packer BM (1987) Early Archean (3.3 to $3.5 \mathrm{Ga}$-old) fossil microorganisms from the Warrawoona Group, Western Austrailia. Science 237: 70-73

Semikhatov MA, Gebelein CD, Cloud P, Awramik SM and Benmore WC (1979) Stromatolite morphogenesis - progress and problems. Can J Earth Sci 16: 992-1015

Sleep NH, Zahnle KJ, Kasting JF and Morowitz HJ (1989) Annihilation of ecosystems by large asteroid impacts on the early Earth. Nature 342: 139-142

Starr MP, Stolp H, Trüper HG, Balows A and Schlegel HG (eds) (1981) The Prokaryotes, Vol 1, 1102 pp. SpringerVerlag, Berlin

Strother PK and Barghoorn ES (1980) Microspheres from the Swartkoppie Formation: A review. In: Halvorson $\mathrm{HO}$ and Van Holde KE (eds) The Origins of Life and Evolution, pp 1-18. AR Liss, New York

Thrailkill J (1976) Spelothems. In: Walter MR (ed) Stromatolites, pp 73-86. Elsevier, Amsterdam

Valentine JW and Erwin DH (1987) Interpreting great developmental experiments: The fossil record. In: Raff RA and Raff EC (eds) Development as an Evolutionary Process, pp 71-107. AR Liss, New York

Valentine JW, Awramik SM, Signor PW and Sadler PM (1991) The biological explosion at the PrecambrianCambrian boundary. In: Hecht MK, Wallace B and MacIntyre RJ (eds) Evolutionary Biology, Vol 25, pp 279-356. Plenum, New York

Vermaas W (1989) The structure and function of Photosystem II. In: Bowler J and Mallin R (eds) Techniques and New Developments in Photosynthesis Research, NATO ASI Series, Vol 168, pp 35-59. Plenum, New York

Vidal $G$ (1984) The oldest eukaryotic cells. Sci Am 250: $48-57$ 
Walker JCG (1978) Oxygen and hydrogen in the primitive atmosphere. Pure Appl Geophys 116: 222-231

Walker JCG, Klein C, Schidlowski M, Schopf JW, Stevenson DJ and Walter MR (1983) Environmental evolution of the Archean-Proterozoic earth. In: Schopf JW (ed) Earth's Earliest Biosphere, pp 260-290. Princeton Univ. Press, Princeton

Walsh MM (1992) Microfossils and possible microfossils from the early Archean Onverwacht Group, Barberton Mountain Land, South Africa. Precambrian Res 54: 271-293

Walsh MM and Lowe DR (1985) Filamentous microfossils from the 3,500-Myr-old Onverwacht Group, Barberton Mountain Land, South Africa. Nature 314: 530-532

Walter MR (1976a) Geyserites of Yellowstone National Park: An example of abiogenic 'stromatolites'. In: Walter MR (ed) Stromatolites, pp 87-112. Elsevier, Amsterdam

Walter MR (1976b) Introduction. In: Walter MR (ed) Stromatolites, pp 1-3. Elsevier, Amsterdam
Walter MR (1983) Archean stromatolites: Evidence of the earth's earliest benthos. In: Schopf JW (ed) Earth's Earliest Biosphere, pp 187-213. Princeton Univ. Press, Princeton

Walter MR, Buick R and Dunlop JSR (1980) Stromatolites 3,400-3,500 Myr old from the North Pole area, Western Australia. Nature 284: 443-445

Ward DM, Weller R, Shiea J, Castenholz RW and Cohen Y (1989) Hot spring microbial mats: Anoxygenic and oxygenic mats of possible evolutionary significance. In: Cohen $Y$ and Rosenberg E (eds) Microbial Mats, pp 3-15. Am Assoc Microbiol, Washington, DC

Worrell GF (1985) Sedimentology and mineralogy of silicified evaporites in the basal Kromberg Formation, South Africa. Unpublished M.A. Thesis, Lousiana State University, $152 \mathrm{pp}$

Woese CR (1987) Bacterial evolution. Microbiol Rev 51: 221-271 